\title{
IbM of Small Medium Enterprise of Coconut Milk and Liquid Smoke from Coconut Shells
}

\author{
Era Yusraini ${ }^{1 *}$, Halimatuddahliana ${ }^{2}$ and Saharman Gea ${ }^{3}$ \\ ${ }^{1)}$ Department Food Science and Technology, Faculty of Agriculture, Universitas Sumatera Utara \\ ${ }^{2)}$ Departmentof Chemical Engineering, Faculty of Engineering, Universitas Sumatera Utara \\ ${ }^{3)}$ Departmentof Chemistry, Faculty of Mathematics and Natural Sciences, Universitas Sumatera Utara
}

\begin{abstract}
Community service activities funded by BPPTN 2017 has been implemented with one of the partners, who was a small entrepreneur of coconut milk and liquid smoke from coconut shells, held from August to November 2017. Partnership of community service was Mr. Budi Darmanto, who has has his business for 9 years in Medan. The problems facing by the partner were: marketing of the coconut milk was still through the agent, resulting in the low selling price because the cost must be cut off for agent commission. In addition, liquid smoke product from coconut shells still contained impurity (Tar), classified as grade 3 , causing the demand and its selling price became low. Solutions to the problems were 1) opening or enlarging the new commercial market for coconut milk, by assisting them in the handling of halal permits to the MUI of North Sumatra Province and made marketing advertisements through the website; 2) Providing a grant of liquid smoke distillation apparatus, making standard operational procedures (SOPs) to reduce impurities as well as increasing the grade of liquid smoke, to increase the selling price, and also analyzing the quality of distillated liquid smoke. The opening of commercial market of coconut milk and increasing grade of liquid smoke is expected to increase the partner's income and expand his own business.
\end{abstract}

Keywords: Coconut Milk, Community Service, Distillation, Entrepreneur, Liquid Smoke

Abstrak. Kegiatan pengabdian masyarakat dana BPPTN tahun 2017 telah dilaksanakan dengan salah satu mitra yaitu usaha kecil menengah santan kelapa dan asap cair dari batok kelapa dari bulan Agustus sampai November 2017. Mitra pengabdian yaitu bapak Budi Darmanto memiliki usaha santan kelapa dan asap cair dari batok kelapa di kota Medan. Mitra telah menjalankan usahanya selama sekitar 9 tahun. Permasalahan Mitra adalah sebagian besar pasar santan kelapa masih melalui

\footnotetext{
*Corresponding author at: Jalan Prof.A.Sofyan No. 3 Medan, Indonesia

E-mail address: era_yusraini@yahoo.com
} 
agen, sehingga harga jual produk menjadi rendah karena harus dipotong komisiagen. Selain itu, produk asap cair dari batok kelapa yang masih mengandung kotoran (Tar) tergolong asap cair tingkat (grade) 3, yang harga jual dan permintaannya masih rendah. Solusi permasalahan yang dilakukan tim pelaksana adalah 1) membuka atau memperbesar pasar komersial baru untuk santan kelapa, dengan cara membantu dan mendampingi pengurusan ijin halal ke MUI Provinsi Sumatera Utara serta membuatkan iklan pemasaran melalui website; 2) Memberikan hibah alat destilasi asap cair dan membuat standar operasional prosedur untuk mengurangi kotoran serta meningkatkan grade asap cair sehingga dapat memperbesar harga jual serta melakukan uji mutu asap cair hasil destilasi. Pembukaan pasar komersial santan kelapa dan peningkatan grade asap cair diharapkan dapat meningkatkan pendapatan usaha. Mitra pengabdian sehingga dapat mengembangkan usahanya agar lebih maju.

Kata Kunci: Asap Cair, Destilasi, Pengabdian Masyarakat, Pengusaha, Santan Kelapa Received 22 October 2017 | Revised 10 December 2017 | Accepted 20 March 2018

\section{Introduction}

Medan Johor district is situated in the southern city of Medan, about $8 \mathrm{~km}$ from Universitas Sumatera Utara. The boundary of Medan Johor district are : Medan Selayang district in the west, Medan Amplas district in the east, Deli Serdang regency in the south, and Medan Polonia district in the north.

Partnership of community service was a small enterpreneur at JalanPintu Air IV, KwalaBekala village, Medan Johor district, Medan, Mr. Budi Darmanto, producing coconut milk and coconut shells. The raw materials are coconut with main product of coconut milk, charcoal, liquid smoke from coconut shells and also nata de coco from coconut water. In addition, the coconut milk and liquid smoke from coconut shells, has been produced for about 9 years. The waste, such as coconut dregs and coconut shells, are also sold separately.

During that time there has been many improvements made to the processing of coconut milk. The partner has 4 coconut shredders, (Figure 1), coconut milk machine with diesel fuel (solar) and motor 5 house power/HP (Figure 2) with hydroulic type. Coconut shells have been processed into charcoal. The byproducts during the charcoal process are the smoke produced during combustion (the pyrolysis process) that has been muted into liquid smoke and sold in small quantities. Partners have their own pyrolysis and smoke-reducing devices, that are energy efficient, as shown in Figure 3. 
Partner's income from the coconut milk in one month is 250 liter / day x Rp 8000 / liter x 25 working days $=\operatorname{Rp} 50.000 .000$. On the other hand, the earning from the liquid smoke is still low, around 30 liters / month $x$ Rp 15.000 / liter $=\operatorname{Rp} 450.000$, -

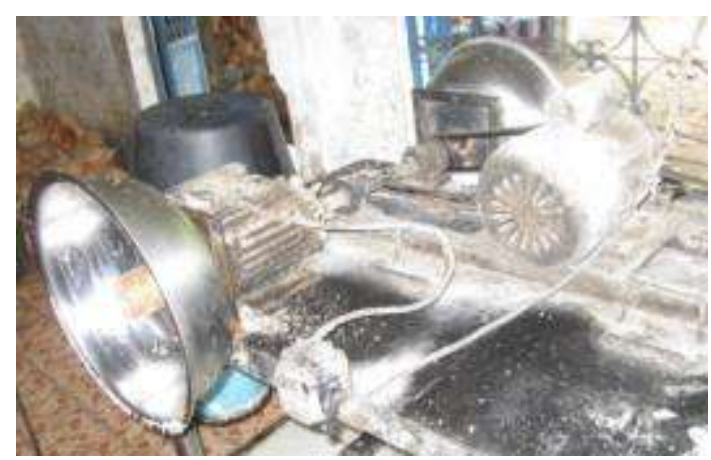

Figure 1. Shredded coconut machine

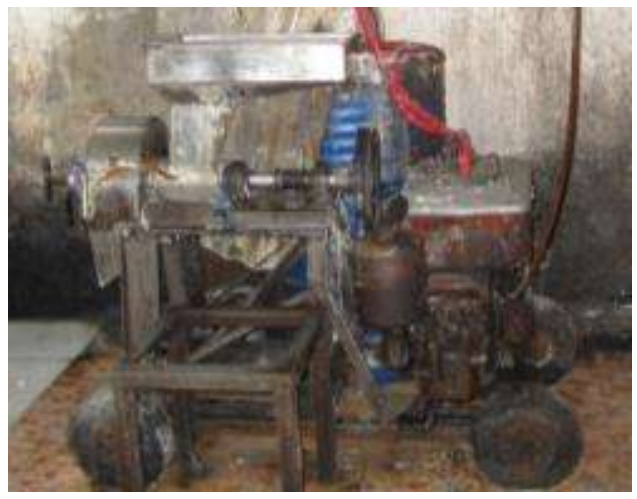

(a)

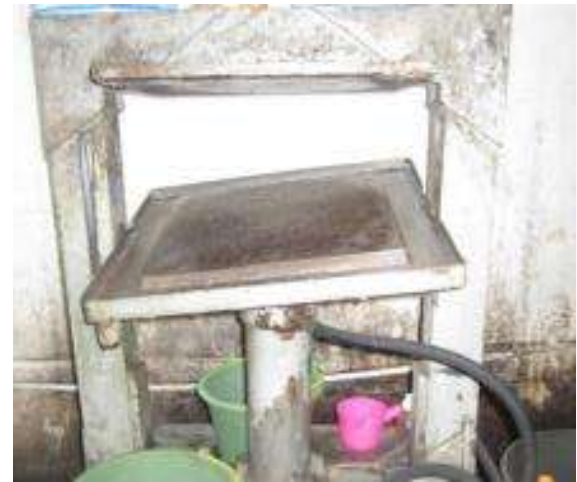

(b)

Figure 2. Coconut milk machine with thread type using diesel fuel (solar) and motor 5HP (a) and also with hydroulic type (b).
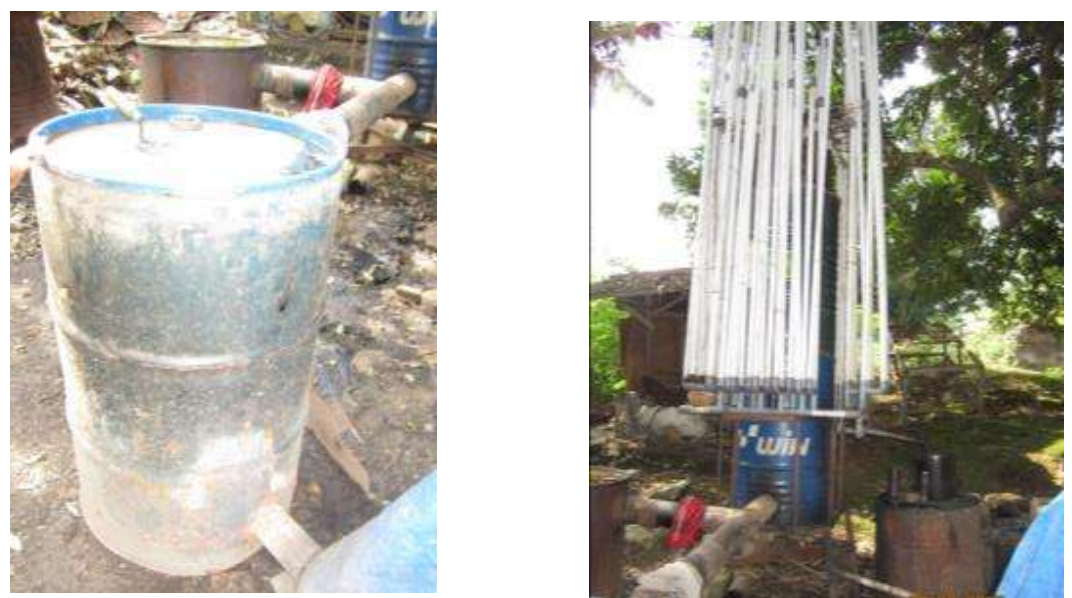

Figure 3. Burning device (pyrolysis process) for liquid smoke

From the described situation analysis, the main priority of the partner's problems are 1) Do not have a wide market, so that most of coconut milk market is still through an 
agent. This condition causes the income from the selling price of the product become low because the fee for agent's commission must be taken away from the earnings; 2) They need to have permission of Halal MUI (Indonesian Ulema Council) to increase product marketing; 3) The liquid smoke still have high amount of dirt or tar (Figure 4), so the selling price and demand become lower. Tar is a term for chemical content in liquid smoke that can be carcinogenic. Liquid smoke that has a high Tar content is usually black or blackish brown in colour.

One way to eliminate the content of Tar is to do the distillation method [1]. The removal of Tar is necessary to increase the selling price of the produced liquid smoke to achieve business feasibility [2].

\section{Method}

The problems in marketing aspect have been solved by the team within six months, by opening a new commercial market of coconut milk and decreasing the amount of dirt (Tar value) of liquid smoke by using distillation apparatus. The distillation was undertaken, because liquid smoke with smaller amount of dirt will have a higher quality or grade.

The procedures to support the problem solving was by doing the implementation of science and technology, providing support and assistance to the workers. The activities to solve the problem include the implementation of science and technology on marketing aspect of coconut milk and liquid smoke production aspects consisting of:

a. Training, mentoring MUI Halal permit and market expansion using website

b. Design and grant a liquid smoke distillation apparatus

c. Analyze the quality of liquid smoke from distillation

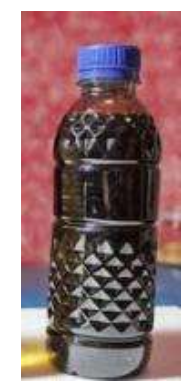

Figure 4. Liquid smoke with high of dirt (Tar)

\subsection{Participation Partner in Activities}


In accordance with the agreement between USU implemention team and the partner, they must participate in terms of:

a. Completing and providing the needed information to prepare halal permit, i.e. a business certificate, the presence of workers in Small Medium Enterprise (SMEs) training to become internal halal auditors held by LPPOM, which will then can assist to create a certificate of halal coconut milk productsfrom LPPOM MUI

b. Providing their time and actively help the team

c. Receiving the grant of production equipment and maintain it including the willingness to fix the minor failure of the equipment in the future.

\section{Results and Discussion}

\subsection{Activities open new commercial markets coconut milk}

The team managed to gain a coconut milk halal certificate from LPPOM MUI (Food Medicines and Cosmetics Assessment Agencies), in North Sumatra Province in early September 2017. Previously, the team was also keen to help in P-IRT permit from the Health Department for coconut milk, but the Health Department can not grant the permit because it is categoried as a perishable, product with only one day shelf life at room temperature, without airtight packaging. So the product licensing certificate that could be made was only Halal MUI permit.

In the end of November 2017, partner has reached the stage of document improvement and process as directed by LPPOM MUI auditor who had already come to visit. The details of partner's last registration history for coconut milk products under the Santan Coco brand can be seen in Figure 5.

Although the Halal permit of partner (Santan Coco) is not finished yet, the team keeps following the plan describing in the earlier proposal, which was making Santan Coco marketing through internet by link https://youtu.be/_jnLc7ykoWQ. The coconut promotional video has been uploaded, and if the halal permit certificate have been obtained, it can be added to the video. The video display can be seen in Figure 6 . 
Figure 5. Halal registration history of Santan Coco
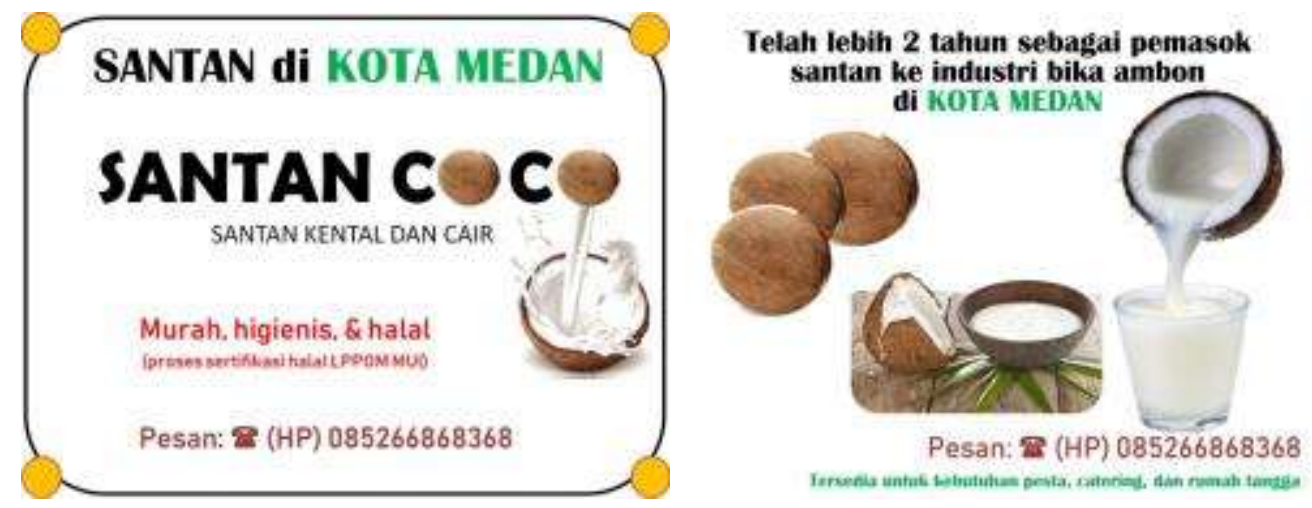

Figure 6. Display marketing website of Santan Coco

\subsection{Monitoring and evaluation activities of the institution}

The institution of community service (LPPM USU) has conducted monitoring and evaluation by visiting the production site of partner (Figure 7). The visit was organised to view, monitored and evaluated the resulting activities by the USU team. During the visit, the team explained that one of the outcomes was designing and granting liquid smoke distillation apparatus according to the needs of the partner.

\subsection{Activity improves the quality or grade of liquid smoke}

Partner needed a distillation apparatus to clean or purify the produced liquid smoke that have not already filtered yet (Figure 4). The USU team has designed and made the liquid smoke distillation apparatus according to the urge and needs of partner. The distillation device is made of stainless steel and has a capacity of 30 liters (Figure 8). A gas or a kerosene stove can be used as the heat to the equipment. In addition, the partnes also want to try using the combustion heat from the burning of coconut shells in a closed drum. The distillation apparatus has been designed and tested using a gas stove to distill liquid smoke. 
Furthermore, the quality parameters of distilled liquid smoke was analised, by comparing the quality of un-distilled liquid (A) and the distilled liquid smoke (B) as shown in Figure 9. The liquid smoke quality (A and B) was further equated to the liquid smoke standards of Japan spesifications as shown in Table 1.
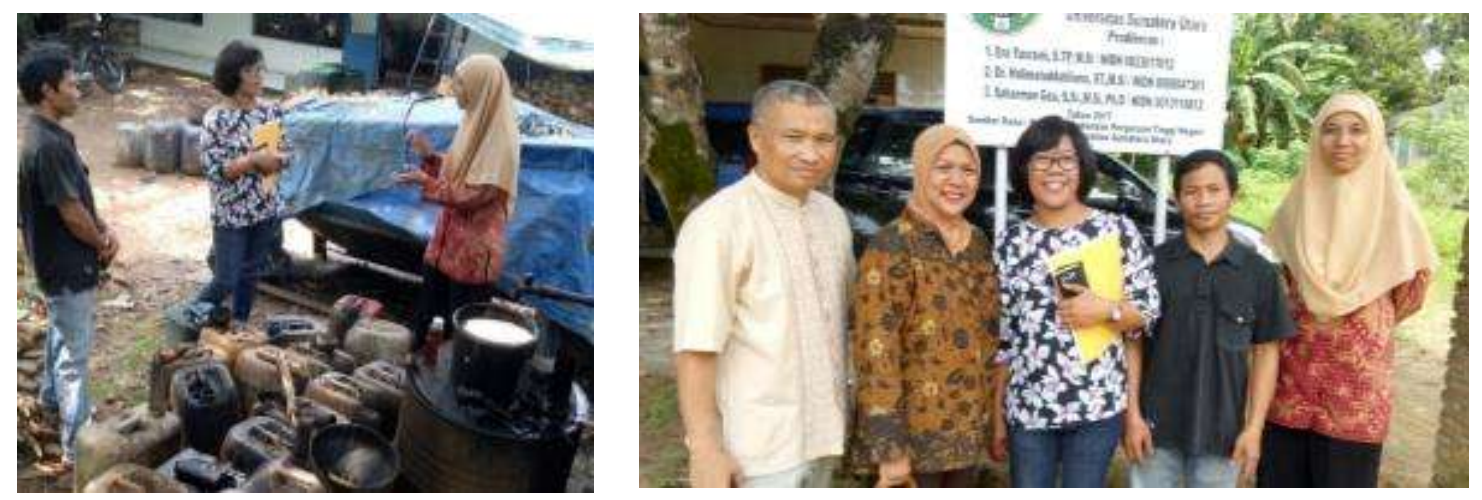

Figure 7. Monev activities at partner's locationJalanPintu Air IV Medan

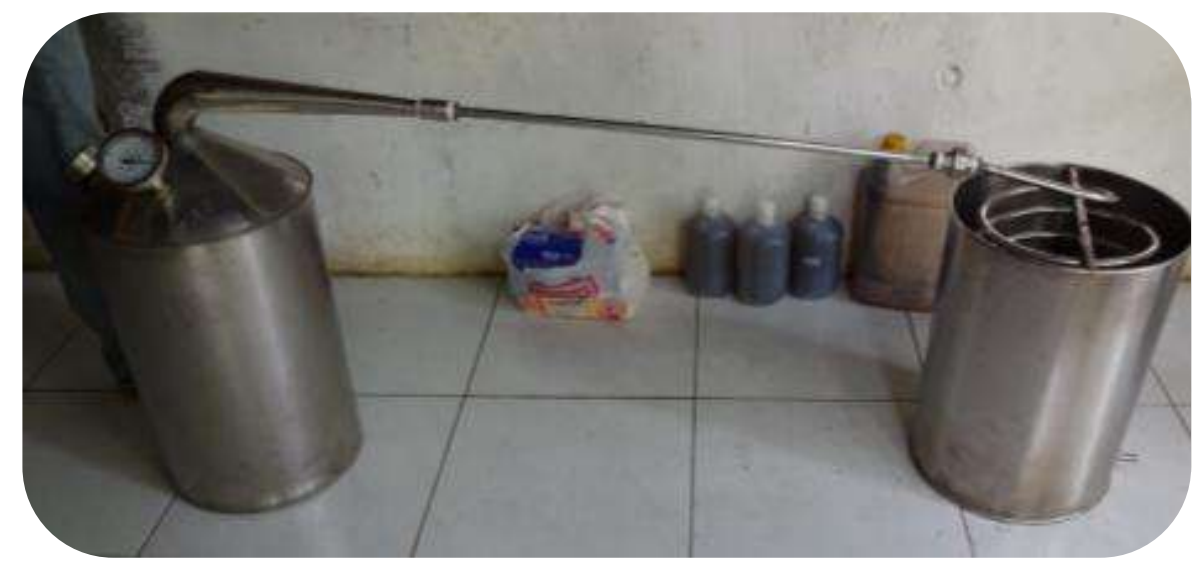

Figure 8. Distillation device of liquid smoke from stainless steel

When compared to liquid smoke standard from Japan, liquid smoke produced by the partner by precipitation and filtration with cotton has met Japan standard. The quality of second type of liquid smoke, distilled liquid smoke after precipitation and filtration, is also accordance with the Japanese standard. However, liquid smoke resulted from sediment of precipitated, filtered and distilled liquid smoke had better condition than the Japanese liquid smoke, in terms of having smaller density, fewer percentage of floating material (almost none), lower soluble solids, and more yellowish color as shown in Table 2.
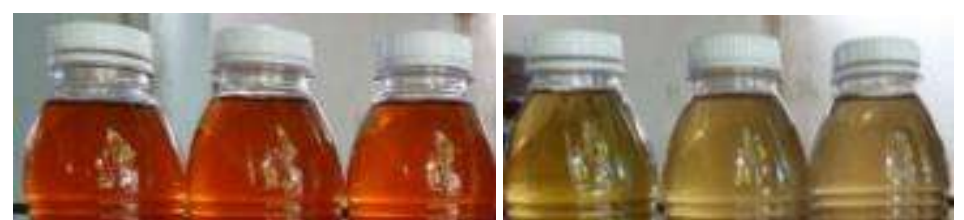
Figure 9. Liquid smoke before (left) and after distillation (right)

Table 1. Liquid smoke quality from Japanese specifications

\begin{tabular}{cll}
\hline No. & Parameter & Liquid smoke quality \\
\hline 1. & $\mathrm{pH}$ & $1,50-3,70$ \\
2. & Spesific gravity $\left(\mathrm{g} / \mathrm{cm}^{3}\right)$ & $>1,005$ \\
3. & Colour & Yellow reddish brown \\
4. & Transparency & Transparent \\
5. & Floating material & No floating material \\
6. & Total acid (\%) & $1-18$ \\
\hline \multicolumn{2}{c}{ Source :Alfian et.al.(2014) $[3]$} &
\end{tabular}

Based on Table 2, by analyzing further test statistic using $t$ test, it is known that there was a different quality between precipitated and filtered liquid smoke and the precipitated, filtered and distilled liquid smoke for all parameters, including $\mathrm{pH}$, specific gravity $\left(\mathrm{g} / \mathrm{cm}^{3}\right)$, and color (L, a, b, and $\left.{ }^{\circ} \mathrm{Hue}\right)$, floating material (\%), total acid (\%) as acetic acid, and total soluble solids ( ${ }^{\circ}$ Brix $)$, dan except for ash content $(\%)$.

From liquid smoke website on trading liquid smoke based on the color, it is known that the liquid smoke with one distillation (Figure 9. right) has similar condition with liquid smoke grade 2 leading to grade 1 (Figure 10).

Liquid smoke grade 1 and 2 can be used for food preservatives such as tofu, noodles, fish and others. Thus, distilled liquid smoke can be sold with higher price. Partners stated that precipited filtered and one distilled liquid smoke can be sold for about Rp 20,000 per liter, compared to precipited and filtered liquid smoke that was only sold at $\mathrm{Rp} 15,000$ per liter. There is a gross profit margin of about Rp 5000 per liter, including labor and fuel. Meanwhile, it is known from the website, that the selling price of liquid smoke grade 1 and 2 each liter can be more than Rp 20.000 .

Table 2. Quality of initial and distilled partner's liquid smoke 


\begin{tabular}{|c|c|c|c|c|}
\hline \multirow[t]{2}{*}{ No. } & \multirow[t]{2}{*}{ Parameter } & \multicolumn{3}{|c|}{ Partner's liquid smoke } \\
\hline & & Initial $^{\text {I) }}$ & $\begin{array}{l}\text { After being } \\
\text { precipitated } \\
\text { and filtered } \\
\text { 2) }\end{array}$ & $\begin{array}{l}\text { After being } \\
\text { precipitated, } \\
\text { filtered and } \\
\text { distilled }^{3)}\end{array}$ \\
\hline 1. & $\mathrm{pH}$ & ND & $2,75^{b}$ & $2,84^{\mathbf{a}}$ \\
\hline 2. & Spesific gravity $\left(\mathrm{g} / \mathrm{cm}^{3}\right)$ & ND & $1,087^{\mathrm{a}}$ & $1,067^{\mathbf{b}}$ \\
\hline 3.a & Colour & $\begin{array}{l}\text { Dark brownish } \\
\text { brown }\end{array}$ & $\begin{array}{l}\text { Reddish } \\
\text { orange }\end{array}$ & Light yellow \\
\hline 3.b & Colour (with camera)* & & & \\
\hline & $\mathrm{L}$ & ND & $23,28^{\mathbf{a}}$ & $34,84^{\mathbf{b}}$ \\
\hline & A & ND & $31,86^{\mathrm{a}}$ & $12,39^{\mathbf{b}}$ \\
\hline & B & ND & $30,59^{\mathrm{a}}$ & $32,15^{\mathrm{b}}$ \\
\hline & ${ }^{\circ} \mathrm{Hue}$ & ND & $43,82^{\mathbf{a}}$ & $68,92^{b}$ \\
\hline 4. & Transparency & Not transparent & $\begin{array}{l}\text { Not } \\
\text { transparent }\end{array}$ & Not transparent \\
\hline 5. & Floating material & Yes & Not visible & Not visible \\
\hline 6. & Filtered material (\%) & ND & $0,215^{\mathbf{a}}$ & $0,021^{\mathbf{b}}$ \\
\hline 7. & Total acid (\%) & ND & $3,97^{\mathbf{b}}$ & $7,80^{\mathbf{a}}$ \\
\hline 8. & Ash content $(\%)$ & ND & $0,045^{\mathrm{a}}$ & $0,036^{\mathrm{a}}$ \\
\hline 9. & $\begin{array}{l}\text { Total soluble solids }\left(^{\circ}\right. \\
\text { Brix })\end{array}$ & ND & $7,17^{\mathrm{a}}$ & $5,63^{\mathrm{b}}$ \\
\hline
\end{tabular}

Noted:

Different letters on a parameter show different test with $t$ test which differ significantly at the level 0.05

${ }^{1)}$ Letter ND : Not determined

${ }^{2)}$ Precipitated and filtered with cotton

${ }^{3)}$ Precipitated, filtered and distilled with the apparatus

* Colour data in RGB obtained from camera photos (Figure 9) using adobe photoshop CS3 and interpreted to L,a,b according to website: http://colormine.org/convert/rgb-to-lab
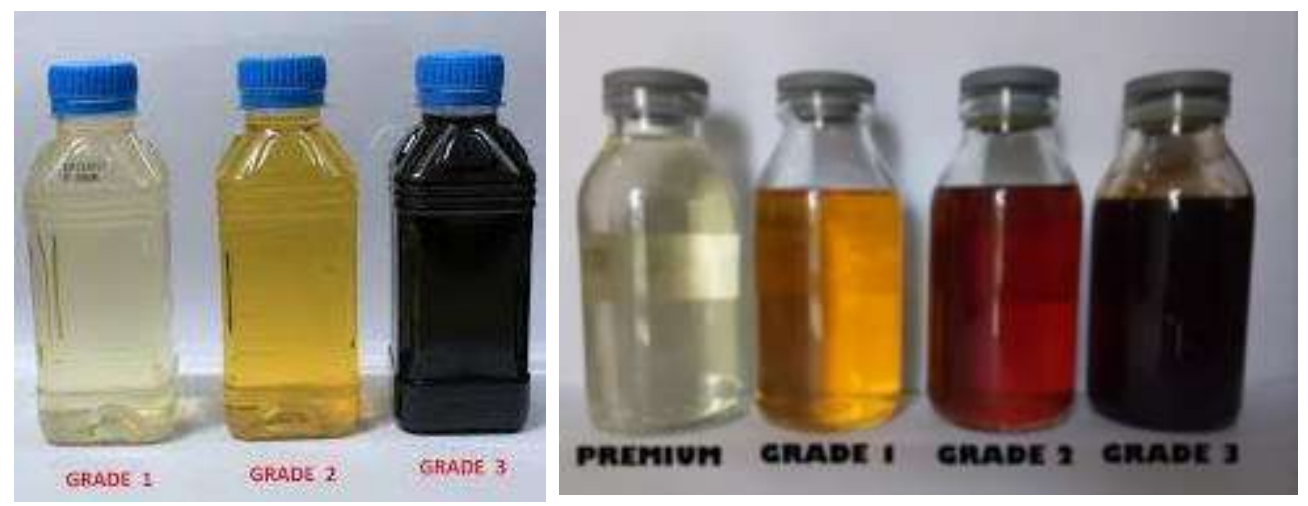

Figure 10. Liquid smoke of some grades

source: http://tokopanjada.blogspot.co.id/) at left and https://www.bukalapak.com/p/food/bumbu/bumbu-mentah/7lwrea-jual-asap-cair-grade-3- at right The team also prepared SOP (Standard Operating Procedure) of liquid smoke for partner. The SOP consists of definitions, benefits, time, materials and equipment along with working principles. According to equipments and working principles drew in the flow chart (Figure 11), partner needs to use a large vat of iron vessel connected to a pipe 
to another iron barrel. Coconut shells without a coir, were burned in the first iron barrel for about 3 hours (1). In the second iron barrel (2) a number of pipes are mounted to 4 meters high, curved at the top (3). Pipe is used to absorb the smoke from the combustion or pyrolysis of coconut shell / pyrolysis. Furthermore, air from the top of the pipe will cool the smoke from the burning of the shell and pass the resulting liquid smoke to the discharge valve (4). Cotton and cloth are added to the faucet to filter the liquid smoke which is then precipitated (5). To improve the quality, liquid smoke (6) is distilled with a distillation apparatus (7) resulting in a purer, better-quality liquid smoke (8) or grade 1-2 which can be used for food preservatives with higher price.

Liquid smoke grade 1 and 2 can be used for food preservatives such as tofu, noodles, fish and others. Thus, distilled liquid smoke can be sold with higher price. Partners stated that precipited filtered and one distilled liquid smoke can be sold for about Rp 20,000 per liter, compared to precipited and filtered liquid smoke that was only sold at $\mathrm{Rp} 15,000$ per liter. There is a gross profit margin of about Rp 5000 per liter, including labor and fuel. Meanwhile, it is known from the website, that the selling price of liquid smoke grade 1 and 2 each liter can be more than Rp 20.000 .

The team also prepared SOP (Standard Operating Procedure) of liquid smoke for partner. The SOP consists of definitions, benefits, time, materials and equipment along with working principles. According to equipments and working principles drew in the flow chart (Figure 11), partner needs to use a large vat of iron vessel connected to a pipe to another iron barrel. Coconut shells without a coir, were burned in the first iron barrel for about 3 hours (1). In the second iron barrel (2) a number of pipes are mounted to 4 meters high, curved at the top (3). Pipe is used to absorb the smoke from the combustion or pyrolysis of coconut shell / pyrolysis. Furthermore, air from the top of the pipe will cool the smoke from the burning of the shell and pass the resulting liquid smoke to the discharge valve (4). Cotton and cloth are added to the faucet to filter the liquid smoke which is then precipitated (5). To improve the quality, liquid smoke (6) is distilled with a distillation apparatus (7) resulting in a purer, better-quality liquid smoke (8) or grade 1-2 which can be used for food preservatives with higher price.

Liquid smoke distillation apparatus symbolically granted to partner on November 18 , 2017 (Figure 12). The partner was very grateful for the equipment grant, because it is in accordance with his urge and needs. Furthermore, the team expected the partner to use and maintain the granted equipments and in turn can increase his profit. The team has 
time limitation, so that unable to monitor further benefits for the partner including his profit after using the tool. However, based on product quality test after using the liquid smoke distillation apparatus, it is known that there is an improvement in product quality. The team supposed that the quality improvement can synergize with the increase of partner's earnings in the future.

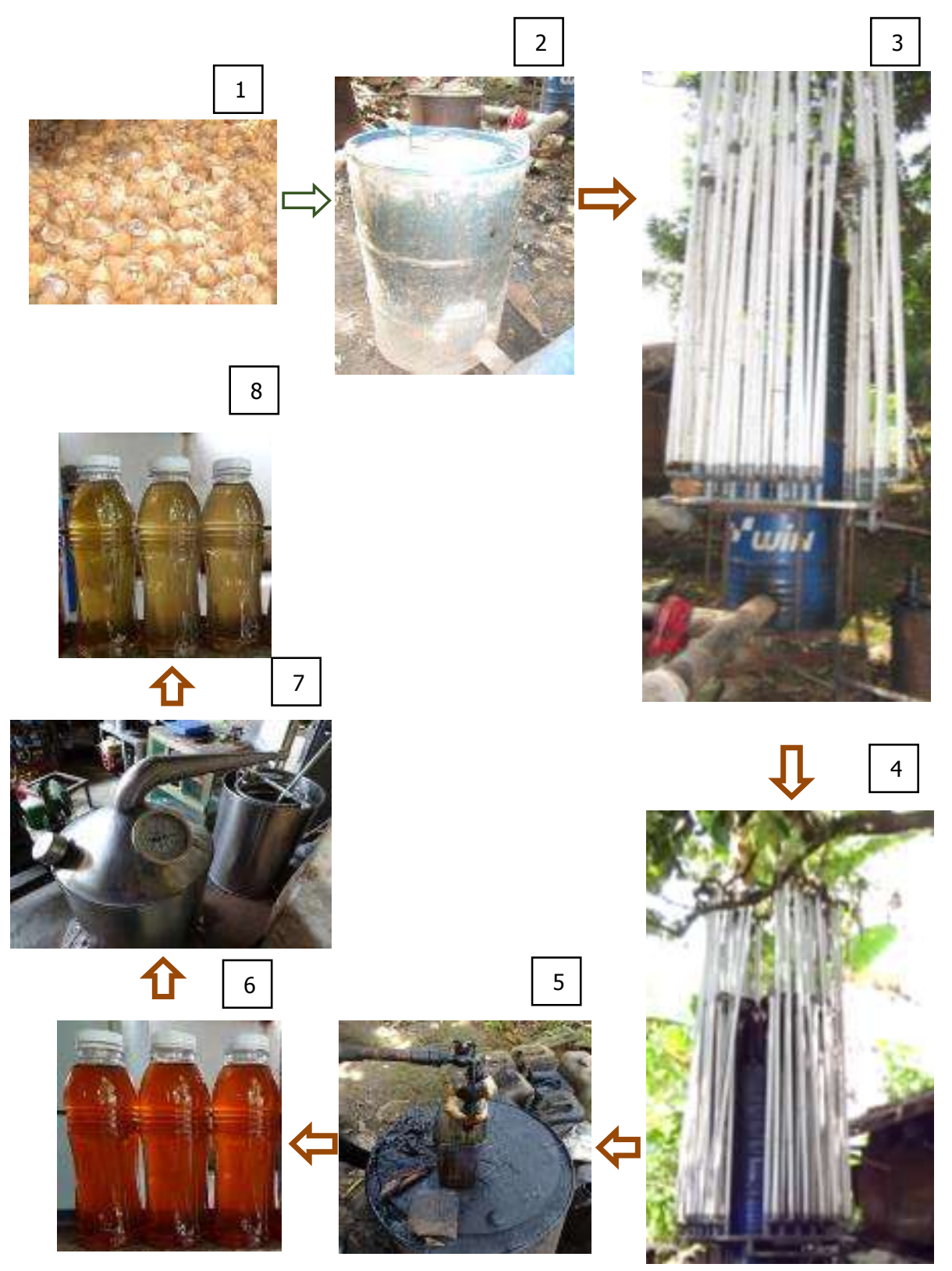

Figure 11. Flowchart of SOP (Standard Operating Procedure) of liquid smoke distillation

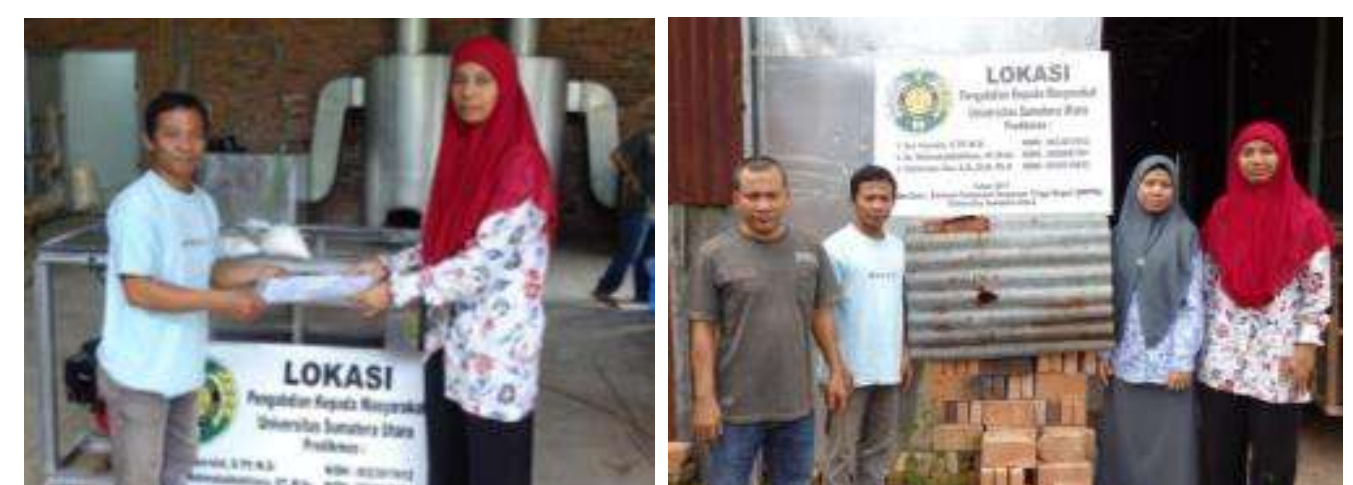


Figure 12. Donation activity of distillation apparatus grant

\section{Conclusion}

Community service activities have been completely done to help a partner, Mr. Budi Darmanto, situated at Jalan Pintu Air 4 Gang Kolam Jaka Medan. The team has provided assistance to partner in obtaining permit Halal of LPPOM MUI of North Sumatera Province and in manufacturing marketing website page for coconut milk products, although the Halal permit not had been uploaded yet on the internet. In addition, the team has also designed and granted a liquid smoke distillation apparatus for partner. The distillation apparatus has a capacity of 30 liters. Based on the results of the quality parameter test, distilled liquid smoke has significantly different with un-distilled liquid smoke in terms of $\mathrm{pH}$, specific gravity, color, percentage of floating material, total acid, and total soluble solids, but had similar ash content. Distilled liquid smoke has better grade leading to higher selling price. All specified output targets have been accomplished. However, an increase of partner's earnings after the implementation of service activities is not known due to limited implementation time. The team anticipated that the improvement of liquid smoke product quality after the use of distillation apparatus could be in line with the increase of partners' earnings in the future.

\section{Acknowledgments}

This article was supported by internal grant community service programs of Universitas Sumatera Utara (BPPTN grant, one year for junior lecturer) number 3224/UN5.2.3.2.1/PPM/2017.

The authors would like also to thank Dr. Hotnida Sinaga, M.Phil (Department Magister Food Science, Universitas Sumatera Utara), for her assistance in proof-reading and correcting of this manuscript.

\section{References}

[1] Yunus, M. 2011. Technology manufacture liquid smoke from coconut shell as food preservative. Jurnal Sains dan Inovasi. 7 (1) : 56-61[Indonesian] 
[2] Andayani, R, Wijaya S, Mulyadi, AF. 2014. Technical feasibility analysis and financial establishment of coconut shell processing unit (liquid smoke and activated carbon).

https://www.researchgate.net/publication/291355231[Indonesian]Accssed

on November 2017][Indonesian]

[3] Alfian, T.A. Prayitno, J.P.G.Sutapa, Budiadi. 2014. The quality of liquid smoke sticks "gelam" (Melaleucasp.).JurnalPenelitianHasilHutan32 (2) : 83-92 [Indonesian]

[4] Shr. Liquid smoke grade 3. https://www.bukalapak.com/p/food/bumbu/bumbu-mentah/7lwrea-jual-asap-cair-gr ade-3. [Accssed on November 2017] [Indonesian]

[5] Slamet, B. Panjada Store. http://tokopanjada.blogspot.co.id/ [Accssed on November 2017][Indonesian] 